\title{
Ceza Sosyolojisi Açısından Türkiye'de Ceza Adalet Politikaları ve Denetimli Serbestlik
}

\author{
Criminal Justice Policies and Probation in Terms of the Sociology of \\ Punishment in Turkey
}

\begin{abstract}
Metin TÜRKMEN*
$\ddot{O}_{z}:$ Suçlar ve cezalar ile ilgili akademik tartışmalar Türkiye'de son yıllarda farklı disiplinlerin ilgi odağ haline gelmiştir. Tüm dünyada 1900'lü yılların başından itibaren farklı disiplinler tarafindan tartışmaya açılan konular, Türkiye'de son yirmi yıldır ve bazı sınırlılıklar içerisinde tartışılmaktadır. Bu alanda tüm dünyada yeni sayılabilecek tartışma alanlarından birisi de ceza sosyolojisi ile ilgilidir. Ceza sosyolojisi, cezalar ve toplum arasındaki ilişkiyi farklı bir bakış açısıyla değerlendirmeyi amaçlamakta ve cezalandırmayı, toplumsal ve tarihsel güçlerin şekillendirdiği karmaşı bir sosyal kurum olarak ele almaktadır. Cezayı belirleyen ve onu şekillendiren bir yapı olarak ceza adalet sistemi ise doğrudan toplumsal yapıyla ilişkili olma yönüyle ceza sosyolojisinin ilgi alanına girmektedir. Ceza adalet sistemine ceza sosyolojisinin sunmuş olduğu teorik pencereden bakıldığında, bu sisteme yön veren politikaların da sorgulanması gerektiği gerçeği ile karşılaşılmaktadır. Ceza adalet politikalarını belirleyen ve şekillendiren en etkili kurumsal yapılardan birisi de denetimli serbestlik kurumudur. Bu kapsam dâhilinde amaç, denetimli serbestlik örneğinden hareketle Türkiye'deki ceza adalet politikalarının, ceza sosyolojisi açısından sorgulamasını gerçekleştirmektir. Bu amaç doğrultusunda ilk olarak ceza sosyolojisi ile ilgili teorik arka plan ortaya konulmuştur. Sonrasında elde edilen teorik açıklamaların toplumsal yapıda tespiti için Türkiye'deki ceza adalet politikaları içerisinde denetimli serbestliğin konumu sorgulanmışıtır. Çalışma bu kapsamda Türkiye'de eksikliği duyulan ceza adaleti alanındaki tartışmalara katkı sunmayı amaçlamaktadır.
\end{abstract}

Anahtar sözcükler: Denetimli Serbestlik, Ceza Sosyolojisi, Ceza Adaleti, Ceza Adalet Politikaları

Abstract: In recent years academic debates about crime and punishment have become the focus of attention of different disciplines in Turkey. Issues that are opened to debate by different disciplines from the beginning of the 1900's in Europe and America, in Turkey have begun in the last twenty years and within some limitations. In the entire world in this area, the sociology of punishment, can be considered a new area of debate. The sociology of punishment aims to evaluate the relationship between punishment and society from a different point of view and also to handle punishment as a complex social institution shaped by social and historical forces. The criminal justice system as a structure that determines and shapes punishment is an interest of the sociology of punishment as it is directly related to the social structure. When looking at the criminal justice system from the theoretical framework about the relationship between punishment and society that the sociology of punishment presents, one is faced with the fact that the policies that direct this system should also be questioned. One of the most effective institution that determine and shape criminal justice policies is the institution of probation. Within this area, the aim here is to inquire into criminal justice policies in terms of the sociology of punishment from the example of probation. With this aim, the theoretical background concerning the sociology of punishment is first put forward. The position of probation in the criminal justice policies in Turkey is questioned in determining the social structure after this theoretical explanation. From this context, this study aims to contribute to the missing debate in the field of criminal justice in Turkey.

Keywords: Probation, Sociology of Punishment, Criminal Justice, Criminal Justice Policies, Turkey

* Dr. Öğr. Üyesi, Artvin Çoruh Üniversitesi, Fen Edebiyat Fakültesi, Sosyoloji Bölümü, Artvin. metinturkmen@artvin.edu.tr. 


\section{Ceza Adaleti ve Ceza Adalet Politikalarına Teorik Bir Giriş}

Türkiye'de ceza adaleti alanında en temel problemlerden birisi, ceza adaletine yön veren birincil etkenlerin toplumsal yapıyla doğrudan bağlantılı olmamasıdır. Toplumsal yapının göz ardı edilmesi ceza uygulamalarında başarısızlığa, başarısızlıkların ortaya çıkması da ceza uygulamaları üzerinde sık değişikliklere, başka bir deyişle ceza adalet politikalarının gündelik politikalarla şekillenmesine neden olmaktadır. Ceza adalet politikalarının beklentileri ile toplumsal ve kurumsal yapı arasında büyük bir uçurum oluşmaktadır. Oluşan uçurumun ortadan kaldırılması için ise ceza uygulamaları üzerinde sürekli ve sık değişiklikler gerçekleştirilmektedir. Ortaya çıkan bu durumun büyük oranda cumhuriyet tarihi boyunca benimsenen modernleşme anlayışının bir ürünü olduğunu da eklemek gerekmektedir. Cumhuriyet tarihi boyunca suç ve ceza alanını şekillendiren hukuk, bir modernleşme aracı olarak görülmüş, toplumsal ve kurumsal değişimin gerçekleştirilmesi için bir araç olarak kullanılmıştır. Hukukun böylesine bilinçli bir modernleşme projesinin aracı pozisyonunda olması, doğrudan suç ve ceza alanını da etkilemekte ve şekillendirmektedir. Türkiye'de ceza adaleti alanında uygulama alanı bulan denetimli serbestlik sistemine de hukuk aracılığıyla modernleşme şeklinde bakmak mümkündür. Denetimli serbestlik temelde benimsenen ceza adalet politikalarının bir ürünü olarak ortaya çıkmaktadır. Dolayısıyla ceza adalet politikalarına yön veren etkenlerin öncelikle teorik arka planının ortaya konulması gerekmektedir. Bu noktada ceza sosyolojisinin sunmuş olduğu tespitlerle ceza adaletine bakılmıştır.

Suç ve cezalar toplum için sürekli bir ilgi alanı ve toplumsal yaşam ve gündelik hayat açısından önemli bir hassasiyetin kaynağı durumundadır. Medyada ve gündelik yaşamın her alanında dile getirilen en temel sorunlar suç ve cezalarla ilgili olmaktadır. Suçlu bireyler dışında toplumun diğer tüm bireyleri suçu, çoğu zaman hastalıklı bir durumun yansıması ve sonucu daima cezalandırma olan, çok karmaşı olmayan bir toplumsal sorun olarak görmektedir fakat suçların ya da suçluların görünmeyen bir yüzü de vardır. Gerçekte varlığının bilindiği fakat çoğu zaman toplum tarafından görmezden gelindiği, suçların ortaya çıkmasında aslında tüm toplumun sorumlu olduğu gerçeği ile yüzleşmek gerekmektedir. Bu yüzleşmeyle bireysel olarak en yakın olunan nokta belki bir suç olayına karışıldığ 1 ya da yakın ilişki içinde olunan birisinin cezalandırıldığı bir an olabilir. Bu yüzleşme noktası suç ve cezalarla ilgili o ana kadar kabul edilen tüm gerçeklerin sorgulanmasına sebep olabilecektir. Toplumun birçok üyesi kendisini suça ve suçlulara çok uzak bir mesafede hissedebilmekte, suçluları toplumun aleyhinde ve karş1sında bir yerde konumlandırabilmektedir fakat her gün sokakta, işte, okulda, kamu kurumlarında, toplumsal yaşamın her alanında suçlularla aynı yaşam alanları ve koşulları paylaşılmaktadır. Suçlular, toplumu, sürekli olumsuz bakış açısıyla yaklaşan, dışlayan, etiketleyen bir karş1 taraf olarak görmektedir. Suçluların toplumdan beklentileri toplumun karşısında bir taraf olarak konumlandırılmak değil, aynı toplumun içerisinde yaşayan bireyler olmaktır. Burada toplum açısından asıl sorun empatik bir taraf değişikliği değil, bu taraflı ayrımı ortaya çıkartan koşulların ortadan kaldırılması gerekliliği olarak ortaya çıkmaktadır. Buradaki suçlu tanımı, ceza almış kişileri ya da cezalarını çekmiş ve topluma geri dönmeye çalışan kişileri içine alacak şekilde anlaşılmalıdır. Toplum sadece suçların ortaya çıkmasında değil, cezalandırma sonrasında suçluların toplum içerisindeki eski yerlerini almasında da önemli bir role sahiptir. Suçlular çoğunlukla toplum tarafindan damgalanmakta ve dolayısıyla topluma tekrar dönüşlerinde zorluklarla karşılaşmaktadırlar. Bu zorlukların aşılması ise büyük oranda ceza adalet sisteminin görev alanına girmektedir. Ceza adaleti ve ceza adalet politikaları doğrudan toplumsal yapıyla ilişkilidir. Ceza adalet alanına sosyolojik perspektifle yaklaşılmak istendiğinde ise bu alanı anlamaya ve çözümlemeye çalışan ceza sosyolojisi ile karşılaşılacaktır. Ceza sosyolojisi açısından bakıldığında toplumsal yapının cezalar üzerinden ve dolayısıyla ceza adaleti alanı üzerinden 
gözlemlenmesinin mümkün olduğu görülecektir. Cezanın tarih içerisindeki geçirdiği değişiklikler ve bu değişikliklerin toplumsal dinamikleri sorgulanmak istendiğinde başvurulacak ilk teorik kaynak ceza sosyolojisi ile ilgili olacaktır.

Ceza sosyolojisi, cezalandırmayı sosyal ve tarihi güçlerin şekillendirdiği karmaşık bir sosyal kurum olarak ele almaktadır. Cezalandırmaya suç oranlarının azaltılması ve suçların önüne geçilmesi çerçevesinde bakıldığında, cezaların yönetilmesi ve suçların kontrol edilmesi şeklinde amaçlarla karşılaşılmaktadır. Ceza sosyolojisi, cezalandırmayı, toplumsal bir kurum olarak görmektedir. Bu kurumun ise toplumsal ilişkiler temelinde, sosyal süreçler olarak izlenmesi gerekmektedir (Garland 1991, 115-120). Cezaya sosyal yapının ve kültürel değerlerin bir üretimi olarak bakmak da mümkündür. Cezalandırmaya toplumda verilen rol, cezalara kimin karar vereceğini, cezalandırmanın nasıl ve ne zaman gerçekleştirileceğini belirler. Toplum, suçluya yaptığının yanlış bir eylem olduğunu, hangi koşullarda ve ne şekilde ifade edecektir? Temel sorun, suçlular üzerinde uygulanacak cezaların, toplum tarafından kabul edilebilecek haklı bir etik durumu yansıtıp yansıtmayacağıdır (Türkmen 2017a). Bu noktada ceza sosyolojisinin sunmuş olduğu bakış açısı üzerinden ceza adalet politikalarının belirlenebileceği gerçeği ile karşılaşılmaktadır.

Teorik açıdan ceza sosyolojisi alanını ilk olarak klasik sosyoloji üstünden görmek mümkündür. Durkheim, cezaya toplumda üstlendiği işlev açısından yaklaşır. Ona göre cezalar toplumsal düzenin sürdürülmesini sağlamaktadır. Cezalar toplumdaki değerleri onaylayarak toplumsal dayanışmayı ilerletirler. Durkheim sosyolojisinde temel kavramlardan birisi olan toplumsal olgu kavramı, maddi ve maddi olmayan toplumsal olgu şeklinde ikiye ayrılmakta, kollektif bilinç ve dayanışma gibi doğrudan gözlemlenemeyen maddi olmayan toplumsal olguların gözlemlenebilmesi için hukuk gibi üzerinde gözlem yapılabilecek maddi toplumsal olgulara başvurulmaktadır. Gözleme olanak vermeyen içsel olguların onu simgeleyen dışsal olgularla gözlenmesi mümkündür (Durkheim 2006). Dışsal olgulardan birisi de hukuktur ve toplumsal dayanışmadaki tüm değişmeler hukuka yansımaktadır. Hukuki yapı ise içerisinde bulunan yaptırım ve cezalarla anlaşılabilir. Farklı dayanışma tiplerini yansıtan cezalandırıcı ve iade edici yaptırımlar bulunmaktadır. Cezalandırıcı yaptırımlar toplumda kollektif bilincin varlığından dolayı mekanik yapıdaki toplumda ortaya çıkar. İade edici yaptırımlar ise suçlara tepki konusunda kollektif bilincin sergilemiş olduğu sert tepkilerin ortadan kalkmasından dolayı organik yapıdaki toplumda ortaya çıkar. Durkheim bu şekilde cezalar üzerinden toplumsal yapının özelliklerini ortaya çıkartmaktadır.

Yaptırımlar iki türe ayrılır birincisi davranış sahibi için acı verici ya da onurunu düşürücü niteliktedir. İkinci yaptırım türünde ise yaptırımlar davranışta bulunanlar için zorunlu bir acı doğurmamakta ve eski durumun yeniden kurulması ve bozulan ilişkilerin olağan biçimine geri döndürülmesi söz konusu olmaktadır (Durkheim 2006, 97). Durkheim açısından modern toplumda cezalar, hem şekil değiştirmekte hem de arkasındaki cezalandırma felsefesi değişmektedir. Modern toplumda kollektif bilinç zayıflar ve cezalar da kollektif bilinç içeriklerinden arınır. Durkheim Ceza Evriminin İki Kanunu çalışmasında da cezaların tarih boyunca geçirdiği değişiklikleri nicelik ve nitelik yönünden inceler. Cezalar nicelik yönünden gittikçe hafiflemekte, nitelik yönünden ise gittikçe hürriyeti bağlayıcı cezalar yani hapis cezası, cezalandırmanın normal şekli haline gelmektedir (Durkheim 1966). Genel anlamda bakıldığında Durkheim sosyolojisinin, hukuku dayanışmanın dıştan görülebilen sembolleri olarak farklı toplumsal tiplerin gözlenmesi için kullandığı görülmektedir. Hukuk ve hukuki yapının içerisinde bulunan suç ve ceza ikilisi bu anlamda Durkheim'ın sosyolojik açıklamaları için başvurduğu önemli ve merkezi kavramlar arasında yer almaktadır. Durkheim'ın bu alandaki teorik açıklamaları 
cezalandırma ile ilgili tarihsel değişimlerin farklı bir bakış açısı üzerinden değerlendirilebilmesine olanak tanımaktadır. Cezalandırıcı anlayışın var olması toplumun mekanik yapıda olduğunu ve modern olmadığını, iade edici ceza anlayışının var olması ise organik yapıdaki bir toplumu dolayısıyla modern toplumu göstermektedir. Durkheim'ın kastettiği iade edici ve onarıcı cezaları günümüzde rehabilitasyon odaklı, onarıcı adalet ve dönüştürücü adalet çercevesinde görmek de mümkündür.

Klasik sosyolojiden devam edildiğinde Weber'in açıklamaları ile karşılaşılmaktadır. Weber açısından bakıldığında cezaların gittikçe ussallaştırıldığı ile ilgili bir açıklama geliştirilebilir. Suçlulara ahlaki değerlerden çok yönetimsel kriterler doğrultusunda yaklaşılmakta ve cezalandırma ise yaptıkları kötülük ya da kötü birisi olarak değerlendirilmeleri ile ilgili değil, işledikleri suçla bağlantılı olarak gerçekleştirilmektedir. Cezaları, ahlaki öfke, cezalandırıcı tutkular veya intikamcı duyguları iletmek için bir araç olarak gören eski yapı, artık işini profesyonel bir şekilde yaparak, mahkeme ve kamuoyuna karşı aşağılayıcı olanları içlerinden ayırarak, ceza sürecini bu etkilerden arındırmak eğilimindedir (Garland 1990, 84). Klasik sosyoloji açısından diğer bir isim olan Marx'tan da söz edilebilir. Marksist düşünce cezaya emek piyasasına yardımcı olan bir ekonomik olgu ve siyasi rolü açısından baskıcı bir devlet aygıtı olarak bakmaktadır. Cezalara yönetici sınıfin ikincil sınıflar üzerinde sosyal ve ekonomik faaliyetlerini korumak ve sürdürmek için uyguladığı bir baskı aracı olarak bakılmaktadır. Marx'ın düşüncesinde nihayetinde her türlü kurum ve dolayısıyla üst yapı olarak görülebilecek hukuk da kapitalist sistemin sürdürülebilmesi doğrultusunda belirlenmektedir. Farklı bir açıdan Marx'ın cezanın şiddetini toplumda emeğin değerine bağladığı ifade edilebilir. Emek toplumda azsa ve değeri fazlaysa cezaların şiddeti daha düşük olmakta, emek bolsa cezalandırma daha şiddetli olmaktadır. Cezalar hafiflemiştir ve değişmiştir çünkü işgücüne duyulan ihtiyaç artmıştır (Türkmen 2017a). Weber ve Marx'ın bu alandaki düşünceleri cezalarla ilgili önemli bir teorik pencereyi aralamaktadır fakat burada daha sınırlı bir incelemeyle Durkheim'ın ortaya koymuş olduğu teorik çerçeve Türkiye tartışması için kullanılmıştır. Bunun nedeni Durkheim'ın sunmuş olduğu teorik çerçevenin burada ele alınan temel sorunsal çerçevesinde Türkiye'nin toplumsal değişim sürecini ya da farklı bir deyişle modernleşme sürecini açıklama potansiyeli olduğu düşüncesidir.

Durkheim'ın teorik açıklamaları çerçevesinde Türkiye'ye bakıldığında, mevcut hukuki yapının temel özelliklerinin cezalandırıcı mı yoksa iade edici mi olduğunu tespit etmek gerekliliği ortaya çıkmaktadır. Cumhuriyet tarihi boyunca sosyal bilimlerin hemen hemen her alanı gibi sosyolojinin temel uğraş alanlarından birisi olan modernleşme olgusu, Türkiye'de halen en temel tartışma konusudur. Durkheim'ın cezalandırıcı hukuk ve onarıcı hukuk ayrımı açısından Türkiye'nin modern hukuki kodlara sahip olduğunu söylemek mümkündür. Mevcut hukuki yapı tüm dünyada kabul edilmiş en gelişmiş cezalandırma anlayışını yani cezalarla ilgili rehabilitasyon düşüncesini temele oturtmaktadır. Bu açıdan Durkheim'ın yaklaşımı bağlamında Türkiye'yi benimsemiş olduğu hukuki yapıdan dolayı organik yapıda ve modern bir toplum olarak kabul etmek mümkündür fakat kanunların ya da ceza usullerinin sadece benimsenmesi yeterli olmamaktadır. Benimsenen kanunların uygulanması da gerekmektedir. Türkiye'de bu alanda temel problemlerden birisi, benimsenmiş olan hukuki yapının topluma uygulanması sırasında ortaya çıkmaktadır. Özellikle benimsenen ceza kanunları uygulama aşamasında birçok aksaklık ve uygulama problemiyle karşılaşmaktadır. Pratikte ortaya çıkan toplumsal yapı ve ceza anlayışı arasındaki uyuşmazlıklar ise ceza kanunları üzerinde sık değişiklikler yapılmasına ve ceza adaletinin gündelik politikalarla belirlenmesine neden olmaktadır. Türkiye'nin mevcut hukuki kodları Durkheimcı perspektiften iade edici ve organik yapıda bir topluma uygun görünmektedir, fakat kanunların uygulanması sırasında ortaya çıkan bazı aksaklıklar ve uygulamadaki 
zorluklar gerçekte cezalandırıcı anlayışa sahip mekanik bir toplumu göstermektedir. Türkiye cumhuriyet tarihinin başında hukuk devriminde Batıdan hukuk kodlarını aldığı gibi son yıllarda da Denetimli Serbestlik örneğinde olduğu gibi Batıdaki hukuki yapıyı kendi yapısına aktarmaya devam etmektedir. Batıdan alınan ceza kanunlarının Türkiye'de pratikte uygulanması sırasında aksaklıklar ortaya çıkmakta, bu aksaklıklar ise ceza kanunları üzerinde kısa bir zaman dilimi içerisinde birçok değişikliğe sebep olmaktadır. Özellikle infaz süreleri üzerinde birçok değişiklik yapılmakta, hatta cezaevlerindeki sayıyı azaltmak için aflara başvurulmaktadır. Çıkarılan af yasaları toplumsal yapı ile ceza kanunları arasındaki uyumsuzluğun bir işareti olarak değerlendirilebilir. Toplum ceza adaleti ile ilgili farklı değerlere ve hassasiyetlere sahip olduğu halde mevcut hukuki yapı aksi bir durumu yansıtabilmektedir. Cezalandırıcı bir anlayış çerçevesinde son dönemde tartışılan idam cezasının tekrar yasal hale getirilmesi gibi, topluma hukuksal yapının belirlediği kurumsal yapı aracılığıyla Batıdan alınan ceza anlayışı verilmeye çalışılmaktadır. $\mathrm{Bu}$ durum ise yukarıda bahsedildiği şekliyle çatışmalara sebep olmakta, toplum suçların cezasız kaldığ1 ile ilgili yaygın bir görüş çerçevesinde hukuka olan güvenini kaybetmektedir. Model alınan ceza sistemlerinin hayata geçirilmesi sırasında ortaya çıkan toplumsal yaşam koşullarının boşlukları cezalar ile ilgili gündelik politikalarla doldurulmaya çalışılmaktadır. Batıdan alınan hukuk kodları bu anlamda Türkiye'nin kendine özgün sosyal, ekonomik koşulları ve toplumsal yapısıyla büyük oranda örtüşememekte ve bu da beraberinde uygulamada istenilen sonuçları üretememektedir. Türkiye'de ceza adaleti alanında teori ile pratik arasında yaşanan boşluklar neticesinde ortaya çıkan sorunlar da bunu göstermektedir. 2005 yılında büyük oranda İngiltere'nin model alınarak ve AB müktesabatının bir parçası olarak aktarılan Denetimli Serbestlik Sistemi de bu sorunları, Durkheim'ın da deyimiyle bu patolojik durumu derinden yaşamaktadır.

Görüldüğü gibi ceza sosyolojisi çerçevesindeki teorik girişim, cezalar üzerinde tespitler yaparak toplumsal yapı ve değişimini anlamaya çalışmaktadır. Bu anlamda cezalar, toplumun gözlemlenebilmesi için bir gösterge durumundadır. Cezalar üzerinde yapılacak tespitlere bir bütün olarak bakılmak istendiğinde ise içerisinde ceza uygulamaları ve çeşitli kurumsal yapıları barındıran ceza adalet sisteminin incelenmesi gerekecektir. Ceza adalet sistemi, bir suçun işlenmesiyle başlayan, araştırma, soruşturma, itham, yargılama, infaz ve infaz sonrası tedbirlere ilişkin süreçleri kapsayan, temel olarak kolluk, savcılık, mahkeme, denetimli serbestlik ve infaz kurumlarının rol aldığı bir sistem olarak tanımlanabilir. Ceza adaletinin ilk amacı, suçu, suç korkusunu ve onların sosyal ve ekonomik maliyetini azaltmaktır. İkinci amacı ise suçlu insanı tümüyle yıkmak değil, ondaki suçluyu cezalandırmak ama aynı kişideki insanı kazanmaktır (Yücel 2011, 55). Ceza politikası ise suça ilişkin kanunların yapılmasını, bu kanunların uygulanması ve infazını, suça karşı toplumsal tepkilerin değerlendirilmesini, suç kontrolünü ve önlenmesini, suçlara ve mağdurlara yardım yollarını ve vasıtalarını kapsar (Yücel 2011, 22). Tarihsel olarak bakıldığında ceza adaleti ile ilgili felsefenin değişen toplumsal dinamikler karşısında daha karmaşıklaştığı görülecektir. Başta cezalandırıcı bir anlayıştan söz edilebilirken sonrasında ıslah edici, onarıcı ve dönüştürücü adalet şeklinde anlayışlar ortaya çıkmıştır. Cezalandırıcı adalete göre cezalar, işlenen suçun karşılığıdır ve cezalandırma diğer bireyler açısından caydırıcı nitelikte olmalıdır. Islah edici adalet cezalandırıcı adaletin katı tutumunu değiştirmek için ortaya çıkmıştır. Temel olarak suçlunun topluma yeniden kazandırılması düşüncesini taşımaktadır. Onarıcı adalet ve dönüştürücü adalet de suçlunun ıslahı düşüncesi üzerine inşa edilmiş olmasına rağmen farklı anlayışları beraberinde getirmektedir. Onarıcı adalet suçun neden olduğu zararın tamir edilmesini hedefleyerek tarafların çözüme aktif bir şekilde katılmalarını öngörmektedir. Temel hedefi bir taraftan suç mağduruna ceza adalet sistemi tarafından sahip çıkılması, diğer taraftan ise suçluya kendi davranışlarının sorumluluğunu üstlenme firsatı vererek suçluyu topluma yeniden kazandırmaktır. Onarıcı adaletin mağdur 
odaklı bir sistem olduğu görülmektedir. Amaç suç nedeniyle ortaya çıkan maddi ve manevi kayıpları gidererek toplumda bozulan düzeni onarmaktır. Dolayısıyla onarıcı adalet hapis cezasını kullanmak istemez. Bunun yerine hapis cezası dışında bir yaptırımla suçlu, toplum ve mağdur arasındaki bozulan ilişkiyi tamir etmek ister. Bu sayede hapis cezasının suçlu üzerindeki yan etkileri de ortadan kaldırılmış olur. Türkiye de dâhil olmak üzere günümüz ceza adalet sistemlerinin en büyük sorunlarından birisi olan cezaevlerinin doluluk oranı onarıcı adalet sisteminin iyi bir şekilde uygulanmasıyla çözüme ulaştırılabilir. Türkiye' de cezaevlerinin doluluk oranının çözümü olarak cumhuriyet tarihi boyunca birçok defa aflara başvurulmuştur fakat afların sorunu çözmediği net olarak görülebilecek durumdadır. Aflar yerine örneğin onarıcı adaletin içinde yer alan uzlaşma kurumunun kullanılması bu tür bir sorunun çözümünde daha aktif bir rol oynayabilir. Uzlaşma kurumu Türkiye'de mevcut sistemde yer alsa da uygulama yönünden henüz istenilen düzeye ulaşamamıştır. Onarıcı adalet düşüncesini hapis cezası açısından daha ileri bir boyuta taşıyan dönüştürücü adalet ise hapis cezasına en son çare olarak başvurulması gerektiğini savunmakta ve temel olarak suçluyu uygun bir yönlendirmeyle dönüştürmeyi amaçlamaktadır. Dönüştürücü adalet açısından hapis cezasının bir işlevi söz konusu değildir. Bunun yerine mağdurun maddi manevi ihtiyaçları göz önünde bulundurularak sanık, mağdur ve toplum açısından en az zararla sürecin yönetilmesi gerekmektedir. Dönüştürücü adalet aynı zamanda sadece suçun başlangıcı ile değil suçun öncesi yani nedenleri ile de ilgilenmektedir. $\mathrm{Bu}$ anlayışta sadece işlenen suç değil suçun sebepleri de değerlendirmeye alınmaktadır (Arıcan 2009, 71-89).

Ceza sosyolojisi açısından bakıldığında; cezalandırmanın tarihsel ve kurumsal olarak geçirdiği değişikliklerin ceza adaleti alanına yansıdığının tespiti yapılabilir. Modern toplum yapısından önce suçlu davranış, tüm topluluğa zarar veren bir eylem olarak değerlendirilmekte ve dolayısıyla toplum tarafından yargılanıp cezalandırılmaktaydı. İlk dönemde cezalar tamamen kişisel öç alma temelinde şekillenmekteydi. Kişisel öç almanın sınırlarının objektif olarak çizilememesi ve suça karşılık gösterilen tepki olarak cezada aşırılıklara gidilebilmesi sonrasında kısas yöntemini ortaya çıkartmıştır. Kısasta belli bir oranda, suç ve gösterilen tepki arasında bir eşitlik söz konusudur. Tarihsel olarak bakıldığında ilk kurumsal gelişme göze göz, dişe diş mantığını taşıyan kısas yönteminin gelişmesi olarak görülebilir ve ilk olarak bu alanda en eski kaynaklar arasında yer alan Hammurabi Kanunları'nda ifade edilmiştir (Roth 2017, 44). Cezalandırma yetkisi önceden kaynağı dinsel öğretiler ya da örf ve adetler olmak üzere tek bir kişide toplanmaktadır. Cezalandırma ile temel amaç suç işlenerek bozulan toplumsal durumun onarılmasıdır. Zamanla suçlara karşı sosyal tepkileri veren kurumlar kurulmaya başlanmış ve cezalandırma yetkisi ise devletin kontrolü altına girmiştir.

Cezalandırma ile ilgili radikal değişiklikler aydınlanma döneminin sunmuş olduğu olanaklarla 18. yüzyılla birlikte başlamıştır. Hümanizma hareketleri, insan hak ve hürriyetleri ile ilgili düşünceler toplumsal açıdan cezalandırma ile ilgili yeni meşruiyet kaynakları aranmasına neden olmuştur. Bu gelişmeler 19. yüzyılda daha ileri boyuta ulaşarak daha kurumsal bir yapının ortaya çıkmasını sağlamıştır ve özellikle cezalandırma şekilleri açısından hapis cezasının temel bir cezalandırma yöntemi olarak benimsenmesi durumunu ortaya çıkartmıştır. Önceden hapis cezası, bir cezalandırma yöntemi olarak benimsenmemekte sadece cezalandırmadan önce suçluların kaçmasını önlemek amacıyla kullanılmaktaydı. 20. yüzyılda temel hak ve özgürlükler konusunda yaşanan değişiklikler ve kurumsal gelişmeler, cezalandırma alanında yeni bir birey anlayışını ortaya çıkartmıştır. Bu birey anlayışı artık cezayı sadece toplumun bozulan durumunun tamir edilmesi amacıyla değil, bir şekilde toplum normları dişına çıkmış kişinin eski durumuna geri getirilerek rehabilite edilmesini ön plana çıkarmıştır. Gelişen rehabilitasyon anlayışı bu yüzyılın sonlarına doğru artık suçları azaltmak konusunda başarısızlığı açısından 
eleştirilmeye başlanmıştır ve ortaya sosyal devlet ve refah devleti anlayışının gelişmesine paralel olarak gelişen ve cezalandırmanın toplumda gerilimlere çözüm arayan, meşruiyetini toplumdan alan bir anlayış içerisinde değerlendirilmesi gerektiğini savunan ve daha geniş anlamda sadece suçluyu değil, mağdur ve suçtan etkilenen diğer toplum üyelerini de cezalandırma sürecinde hesaba katan onarıcı adalet anlayışı (restorative justice) gelişmiştir fakat cezalandırma konusunda gelinen bu nokta da yeterli olmamıştır, toplumsal gelişme ve kurumsal gelişmeye karşılık suç oranlarında halen bir artış olduğu ve önceki anlayışların halen suç oranlarını düşürmediği, toplumda güvensiz bir ortam oluştuğu düşünceleriyle, günümüzde cezalandırmanın temel unsuru olan hapis cezasına en son çare olarak başvurulması gerektiğini savunan, işlenen suçların sebepleri ve neticelerini de hesaba katan dönüştürücü adalet anlayışı gelişmiştir. Genel olarak bakıldığında cezaların, tarihsel süreçte toplumsal gelişmeye paralel olarak belirgin bir farklılaşma içerisinde olduğu görülmektedir. Bu süreç ise cezaya karar veren mekanizmanın değişimi, cezalandırma yöntemlerinde değişiklikle birlikte hapis cezasının ortaya çıkması, yeni bir birey anlayışının ortaya çıkmasıyla cezalandırmanın sadece suçlu açısından değil, suçun etkide bulunduğu alanların da değerlendirilmeye başlanması olarak görünmektedir.

Türkiye'de henüz dönüştürücü adalet anlayışından söz etmek çok mümkün görünmemektedir. Onarıcı adalet anlayışının benimsendiğini fakat mevcut kurumsal yapının beklentilere cevap vermediği, cezaevlerinin doluluk oranından da anlaşılmaktadır. 2004 yılından itibaren ceza adaleti alanındaki büyük reform hareketi, mevcut yapıda önceden var olan rehabilitasyon düşüncesini geliştirmiş, Avrupa'da yaygın olan dönüştürücü adaleti kurumsal yapıya yansıtmak istemiştir fakat sadece mevzuatla yapılan değişikliklerin toplumda istendik değişimlerin gerçekleşmesi için yeterli olmadığı görülmektedir. Ceza adaleti açısından gelişme olarak okunabilecek bu sürecin Türkiye'de bazı çelişkilere de sahip olduğu görülebilir. Cezanın amacı suçları azaltmak ve adaleti sağlamaktır fakat cezalara karar veren mevcut yapı, varlığını korumak ve konumunu güçlendirmek için cezalarla ilgili koşulları ve süreleri kendi lehine değiştirebilmektedir. $\mathrm{Bu}$ durum ise ceza adaleti alanında popülist bir durumu ortaya çıkartabilmektedir. Türkiye'de bu açıdan ceza adaleti alanında popülizmin, gündelik politikalarla belirlenen ceza politikaları ve ceza adaleti alanında sık değişikliklerle tespit edilebileceği iddia edilebilir (Türkmen 2017b). Ceza adalet sisteminin mevcut toplumsal yapıya uygun bir şekilde tasarlanması ya da farklı bir açıdan toplumsal yapı ve benimsenen ceza politikaları arasında bir denge kurmak gerektiği teorik açıdan savunulabilir. Türkiye'de üretilen teoriler sürekli olarak asıl toplumsal yapı göz ard1 edilerek modern toplum olma isteği çerçevesinde şekillendiği için ceza adaleti alanında benimsenen Batının ortaya koymuş olduğu modern anlayışla, cezaların uygulama sahası olan toplum arasında sürekli bir uyuşmazlık ve bunun beraberinde getirdiği uygulama problemleri söz konusu olmaktadır.

Buradan hareketle ceza adaleti ile ilgili dünyada ve Türkiye'de mevcut yapı dikkate alınarak bazı tespitlere ulaşmak mümkündür. Ceza adalet sistemleri tüm dünyada taraf sistemi (adversarial system) ve soruşturmacı sistem (inquisitorial system) olarak ikiye ayrılmaktadır. Soruşturmacı sistemin kökleri Kıta Avrupası hukukuna, taraf sisteminin kökleri ise Anglo-Sakson hukukuna dayanmaktadır. Günümüzde soruşturmacı sistem geçerliliğini büyük ölçüde yitirmiş, taraf sistemi ön plana çıkmıştır. Soruşturmacı sistemde hâkim ve mahkeme daha önemli bir pozisyondadır. Savunma ve iddia makamının rolleri kısıtlı durumdadır. Yargılama faaliyeti tamamen hâkimin kontrol ve insiyatifi altındadır. Taraf sisteminde ise iddia ve savunma makamları ön plana çıkmaktadır. Hâkimin rolü kısıtlanmıştır. Nihai karar genellikle jüri tarafından verilmektedir. Taraf sisteminde iddianame pazarliğ (plea bargaining) ve çapraz sorgu (cross examination) ön plana çıkmaktadır. Türkiye esas olarak Kıta Avrupası hukukuna dâhil olarak soruşturmacı sistemi benimsemiştir. Bununla birlikte çapraz sorgulamanın ve uzlaşmanın dâhil edildiği karma 
bir işbirliği sistemine sahip olduğu da ifade edilebilir. İddianame pazarlığı ise sanığın suçu kabul etmesi karşılığında temel olarak daha az ceza ile kurtulmasıdır. Bu kurum Türkiye sisteminde mevcut değildir fakat yargı sisteminin hızlandırılması kapsamında soruşturmacı sisteme özgü bir iddianame pazarlığı geliştirilebilir. İddianame pazarlığı Türkiye'deki sisteme tam olarak uymamaktadır. Mevcut sistemde ceza muhakemesi ile hâkim kendi yapacağı ya da yaptıracağı araştırmalar sonucu maddi gerçeği ortaya çıkartmakla yükümlüdür. İddianame pazarlığı suçun kabulünü maddi gerçeğin ortaya çıkartılması için yeterli görmektedir (Arıcan 2009, 51-70). Yine de Türkiye'de ceza adaleti alanında temel problemlerden birisi olarak gözüken yargılamanın makul sürede gerçekleştirilememesinin aşılabilmesi için bu kapsamda fakat Türkiye'ye uygun benzer uygulamaların gerekliliği ortaya çıkmaktadır.

Ceza adaleti alanında tüm dünyada ve Türkiye'de temel sorun alanlarından birisi de etkinlik ve verimlilik üzerinedir. Ceza adaletinin etkinlik ve verimlilik kriterleri olarak adil yargılama, muhakemenin makul sürede yapılması, cezanın caydırıcılığı, infaz, teknolojinin kullanımı, toplam kalite ve mahkeme yönetimi olarak sıralanabilir. Adil yargılama kişisel hak ve özgürlükler bakımından sanığa güvence sağlamakta ve suç işleyenlerin hak ettikleri cezaya çarptırılacağına dair topluma güvence vermektedir ve hukuk devleti ilkesine bağlı olarak adalete güvenle ilişkilidir. Türkiye'de özellikle son yıllarda hukuka olan güvenin düşük olmasının önemli sorunlardan birisi olarak görülmesi, adil yargılama ile ilgili de sorunların olduğunu göstermektedir. Bu kapsamda diğer bir sorun ise yargılamanın makul sürede yapılamamasıdır. Avrupa İnsan Hakları Mahkemesinin Türkiye'de bu alanda gördüğü en büyük eksikliklerden birisi de bu durumdur. Yargılamanın makul sürede yapılamamasının başlıca nedenlerinden birisi, soruşturma ve kovuşturmaları uzatan faktörlerin bulunmasıdır. Mahkemelerin üzerindeki aşırı iş yükü bu anlamda hâkim ve savcıların üzerinde büyük bir baskı oluşturmaktadır. Bunun yanında hâkim ve savcıların atama ve terfi sisteminden kaynaklanan sorunlar da bulunmaktadır. Hâkimlerin terfi etmek için belli miktarda dosyayı Yargıtay onayından geçirmek zorunda bırakılması sorunsuz ve basit dosyalara daha fazla ilgi gösterilmesine neden olmaktadır. Daha sorunlu ve karmaşık dosyalar ise ötelenmeye çalışılmaktadır. Bunun yanında sık kanun değişiklerinin yapılması mevcut davalarda Yargıtay aşamasında bozmalara neden olmakta, bu durum mahkemelerdeki dosya yükünün de artmasına neden olmaktadır. Soruşturma ya da kovuşturma aşamalarının uzun sürmesi toplumda suçların cezasız kaldığı şeklinde bir algı oluşturmakta bu durum ise cezalardan beklenen en büyük faydalardan biri olan caydırıcılık özelliğinin kaybolmasına neden olmaktadır. Son yıllarda Türkiye'de basit sebeplerden dolayı işlenen suçlar göz önünde bulundurulduğunda bu durum daha çok netlik kazanmaktadır. Yargılama uzadıkça dürüst vatandaşlar açısından vergi yükünde de bir artış ortaya çıkmaktadır çünkü uzayan her dava devlet bütçesine bir mali külfet de oluşturmaktadır. Yargılamanın hızlandırılması amacıyla Türkiye'de son dönemde uygulamaya geçirilen kayda değer bir uygulama uzlaşma kurumudur fakat bu uygulamayla ilgili henüz beklenen uygulama sonuçları elde edilememiştir.

Ceza adalet sisteminin etkinliğinden bahsedilince ilk akla gelen özelliklerden birisi de cezanın caydırıcılığıdır. Türkiye açısından bakıldığında ceza adalet sisteminin toplum açısından güvenirliğinin uzun süren yargılamaların olması, ceza kanunlarının kısa zaman aralıklarında sık sık değişmesi gibi farklı nedenlerden dolayı düşük olduğu görülmektedir. Bu durumun en büyük sebeplerinden birisi de suç işleyenlerin hak ettikleri cezayı almadıkları ya da alsalar bile bu cezanın genel af ya da örtülü aflarla tam olarak infaz edilmediği düşüncesinin toplumda yaygın olarak paylaşılmasıdır. Örtülü ya da açık aflar yanında kamu davasının ertelenmesi ve hükmün açıklanmasının geri bırakılması uygulamaları da sistemin caydırıcılık etkisi üzerinde olumsuz etki oluşturduğu yönünde eleştiriler bulunmaktadır. Türkiye'de afların çıktığı dönemlerin hemen sonrasında işlenen suçlarda büyük bir artışın olduğunu gözlemlemek mümkündür. Anlaşılacağı 
üzere ceza adalet sistemi ile ilgili asıl sorunlardan birisi cezaların ağır ya da hafif olması durumu değil cezanın uygulanması, başka bir deyişle cezanın infazı ile ilgilidir. Toplum cezanın kaçınılmaz olduğu düşüncesine sahip olması gerekirken bu durum Türkiye'de sürekli bir tartışma konusudur. Aflar ya da kanun değişikliklerinden kaynaklanan örtülü aflar ve infazla ilgili üzerinde çok düşünülmeden yapılan düzenlemeler ceza adalet sistemi üzerinde büyük bir bask1 oluşturmaktadır (Arıcan 2009, 137-175). Ceza adalet sisteminin etkinlik ve verimliliği, yargılamanın makul sürede bitirilmemesi hem ceza adaletinin etkinliğini olumsuz etkilemekte hem de kaynakların verimsiz kullanılması sonucunu doğurmaktadır. Gözaltına alınan şüphelilerin büyük çoğunluğunun savcılık veya mahkeme tarafindan salıverilmesi ya da hakkında kamu davası açılan sanıkların büyük bir çoğunluğunun yargılama sonucunda beraat etmesi durumlarının varlığı, etkinlik ve verimlilik adına önemli sorunlar bulunduğunu ifade etmek için yeterli görünmektedir.

Türkiye'de ceza adalet sisteminin dayandığı temel yasal düzenlemeler birçok açıdan ceza adaleti alanında etkinliğin ve verimliliğin sağlanmasına dönüktür fakat temel sorun, yasal mevzuatla çizilen ideal tablonun, toplum içerisinde uygulanmasına geçildiğinde ortaya çıkmaktadır. Mevcut toplumsal yapı cezalandırma ile ilgili farklı bir perspektifi yansitırken, yasalar, benimsenen ve olmasi arzulanan ideal bir tabloyu yansitmaktadır. Genel anlamda cumhuriyet tarihi boyunca yabancı olunmayan bir anlayışla önce hukuksal düzenlemeler yapılmakta, sonrasında ise hukuksal düzenlemelerle sınırları çizilen kurumsal yapının ve dolayısıyla toplumun bu düzene uyum göstermesi beklenmektedir. Farklı bir deyişle hukukun modernleşmek için araçsal durumu, ceza adaleti gibi toplumsal yapıyla doğrudan ilişkili olan bir alanın da şekillendirilmesi amacıyla kullanılmaktadır fakat görüldüğü gibi bir toplumda ceza adaleti birçok açıdan toplumun temel dinamiklerine bağlı ve paralel olarak gelişebilmektedir. Ceza adaletinin toplumsal yapının dışında veya üstünde bir yerde konumlandırılması bu alandaki uygulamaların başarısızlı̆̆ına neden olmaktadır. Türkiye'de özellikle diğer kanunlardan daha çok ceza kanunlarının çok sık aralıklarla değiştirilmesinin nedenlerinden birisi bu durumdur. Sadece ceza kanunları üzerinde yapılan sık değişikliklerin tespit edilebilmesi bile bahsedilen bu çatışmayı ortaya koyabilecek potansiyeldedir. Sonuçta kanunların değiştirilmesi ve yerine daha iyilerinin konulması olumsuz bir durumu yansıtmamaktadır. Buna karşı1ık aynı kanun maddesinin altı aylık periyotlar içerisinde değiştiğinin gözlenmesi bile bu alanda bir sorunun olduğunu gösterecektir. Bu kapsamda ceza adalet uygulamaları arasında tüm dünyada önemli bir konuma sahip olan denetimli serbestlik sistemi de Türkiye'de uygulanmaya başladığı andan itibaren birçok değişiklik geçirmiştir. Denetimli serbestlik sistemi üzerindeki sorunlar sadece sık değişiklikler ve uygulama belirsizlikleri temelinde değil, bu sistemin Avrupa Birliği uyum süreci ile ilişkili olarak siyasi amaçlar için kullanılması durumuyla da ilişkilidir. Bu sistem $\mathrm{AB}$ uyum sürecinde müktesabatın bir parçası olarak Türkiye'den istenen ödevlerden birisidir. 2004 yılında ceza alanındaki reform hareketiyle birlikte yasal düzenlemeler yapılmış ve Avrupa ve Amerika'da Probation adı altındaki sistem, Türkiye'ye denetimli serbestlik sistemi olarak aktarılmıştır. Ceza adaleti alanındaki reform, Türkiye'ye bu alanda birçok radikal değişikliği beraberinde getirmiştir. Reformla getirilen denetimli serbestlik sistemi, yine AB'nin desteklediği çeşitli projelerle birlikte Türkiye'deki kurumsal yapıya yansıtılmıştır. Batıda çok yönlü ve özellikle sivil toplum desteğinin büyük bir yer kapladığı bu sistem, Türkiye'de büyük bir acelecilikle ve büyük oranda İngiltere örneğinin model alınmasıyla aktarılmış ve hemen uygulamaya geçirilmiştir.

\section{Denetimli Serbestliğin Gelişimi ve Türkiye Gerçeği}

(Bu bölümde Metin TÜRKMEN'in 2015 yılında, Prof. Dr. Yıldız AKPOLAT danışmanlığında “Rehabi- 
lite Edici Bir Infaz Türü Olarak Probation Üzerine Sosyolojik Bir Analiz" başlıklı doktora tezinden faydalanılmıştır).

Denetimli serbestlik sistemini ceza adaleti alanındaki gelişmelerin ve toplumsal dinamiklerin farklılaşmasının bir ürünü olarak görmek mümkündür. Aydınlanmadan itibaren birey anlay1şının farklılaşması, sonrasında modernleşmenin sunmuş olduğu imkânlarla hak ve özgürlükler alanındaki gelişmeler, cezalandırma alanında köklü değişiklikleri ortaya çıkarmıştır. Bu gelişmeler cezalandırma ile ilgili orantısız cezalandırma anlayışını yıkmış ve toplumun bozulan durumunun tamir edilmesi yerine suç işleyen bireyin topluma yeniden kazandırılması, bir daha suç işlememesi ve toplumun korunması düşünceleriyle birlikte rehabilitasyon ve onarıcı adalet düşüncelerinin ortaya çıkışını sağlamıştır. Bu aşamadan sonra artık toplum normları dışına çıkarak sapmış olan bireyin tekrar topluma uyumlu birisi haline getirilmesi temel bir yaklaşım olarak belirmiştir. Farklı bir açıdan da bu durumu tespit etmek mümkündür. Değişen toplumsal dinamikler ve gelişmeler de örneğin sanayi devrimi ve sonraki süreçte toplumun çeşitli alanlarında özellikle ekonomik alandaki değişiklikler, öncesinden farklı olarak bireyin de toplumda bir görev üstlenen ve toplumu tamamlayan, toplumun temel bir parçası olarak kabul edilmesinin önünü açmıştır. Her birey toplumda bir görev üstlendiğine göre toplum normları dışına çıkanların da tekrar topluma kazandırılması ve geri dönüşleri, doğal olarak bir gereksinim olarak görülmektedir. Denetimli serbestlik sistemine genel anlamda rehabilite edici bir ceza infaz türü olarak bakmak yerinde olacaktır (Türkmen 2018). Sistemin 1900'lü yılların başında ilk uygulama yıllarında bile cezalandırmanın sebep olabileceği yıkıcı etkilerin azaltılması ve suçluların topluma kazandırılması düşüncelerinin olduğu görülmektedir. Günümüzde dünyanın birçok yerinde uygulanan bu sistem, en özet şekilde hapis dışı alternatif yaptırımlara mahkûm edilen, cezası ertelenen, şartla salıverilen ya da şartlı cezaya mahkûm edilen kişilerin, denetim, gözetim veya tedaviye tabi olarak belirlenen yaptırımlara tabi olmasıdır (Nursal \& Ataç 2006). Denetimli serbestlik kapsamına giren suçlular, sert cezalara karşılık onları toplum içerisinde belirtilen koşullar ile birlikte kontrol altında tutan bazı uygulamalar aracılı̆̆ıyla bir alternatifle karşılaşırlar. Kavram bazı ilke ve değerlerle ilişkisinden dolayı bu alanda sembolik bir öneme sahiptir. Sembolik değeri, insanla ilgili etik değerlerin değişmesi, rehabilite idealinin gelişmesi ve sosyal çalışma alanındaki değerlerin gelişmesiyle ve geçmişle günümüz modern toplumu arasındaki bağlantının kurulmasıyla ilgilidir (Canton \& Hancock 2007). Bu kısımda denetimli serbestlik sisteminin dünyada ve Türkiye'de gelişiminin toplumsal yönü ortaya konulması amaçlanmıştır. $\mathrm{Bu}$ amaçla tarihsel ve bazı güncel tespitler üzerinde durulmuştur. Bu tespitler toplumsal gelişmeye bağlı olarak değişen ceza uygulamalarını ve bu ceza uygulamaları içerisinde denetimli serbestliğin konumunu sorgulamaktadır.

Aşırı ceza uygulamalarının ve cezaevlerinin zorlu koşullarının üzerindeki insani kaygıların artmasının, cezalandırma pratiğinde de değişikliklerin ortaya çıkmasını sağladığı ifade edilebilir (Vanstone 2008). Denetimli serbestliğin ortaya çıkışından itibaren üzerinde birçok tartışma söz konusudur. Temel tartışmalar bu sistemin cezalandırmaya karşılık bir tedavi öngörmesiyle ilgilidir. Farklı bir deyişle bu süreç cezalandırıcı anlayıştan rehabilitasyon anlayışına geçiş aşamasının sancılı sürecini yansıtmaktadır. 19. yüzyılda ilk ortaya çıkışı sivil toplum temelli ve gönüllülerin girişimleriyle suç işleyen kişilere rehberlik yapma amaçlarıyla şekillenmiştir. Başlangıçta misyonerler tarafından gerçekleştirilen çalışmalar söz konusudur ve daha çok alkol tüketimi ve bağımlılığına bağlı suçlarla ilgili çalışmalar ve dini etkilerle insanların Hıristiyanlık özelliğine bakılarak onları ağır cezalardan kurtarmak amaçlı uygulanmıştır. Sonrasında bu amaçla çalışan misyonerler resmi makamlar tarafindan kabul edilmiş ve uygulamalar zamanla devlet tarafından resmi olarak tanınmıştır. İlk yasal alt yapı denetimli serbestliği bir cezalandırma aracı ya da cezalandırma şekli değil, kişilere tavsiyede bulunan ve yardım eden bir 
kurum olarak görmüştür. Bu anlayış, sonrasında rehabilitasyon ve toplumun korunması şeklinde değişmiştir (Worrall \& Hoy 2005). 1878 - 1920 yılları arasında denetimli serbestlik birçok ülkenin yasalarında yer almaya başlamıştır. 1930'lu yıllardan itibaren sistem üzerindeki değerler değişmeye başlamış ve sosyal hizmetler alanında gelişmeler, tıp, sosyal yardımlaşma ve tedavi alanındaki modellerin etkisiyle denetimli serbestlik, teşhis edebilen, profesyonel müdahaleler yapabilen ve eğitim gerektiren bir alan olmaya başlamıştır. Bu şekilde refah toplumu düşüncesini öne çıkaran bir yapıya kavuşmuş ve sistem olarak rehabilitasyon, topluma yeniden kazandırma ve bireyselleştirilmiş vaka çalışmaları yapan sosyal refah projesi olarak kabul edilmeye başlanmıştır (Chui \& Nellis 2003). Sonrasında suç problemi, toplum içerisinde bir yer bulmakta zorlanan ve dezavantajlı bireylerin ve ailelerin yardım ve desteğe ihtiyacı şeklinde görülmeye başlanmıştır. Bu alandaki refahçı anlayış 1950'li yıllarda son bulmuş ve 1970'lerde daha karmaşık bir yapıyla bir sosyal çalışma alanı haline gelmiştir. Bu yılları aynı zamanda denetimli serbestlik için altın yıllar olarak kabul etmek de mümkündür. 1960 yıllarından 1970'lerin ortalarına kadar tedavi yaklaşımı etkili olmuş, 1970'lerin ortalarından sonra gözaltında iyileştirme, 1980'lerde toplum içinde ceza, 1990'ların ilk yıllarında, toplumun korunması, yine 1990'larda ne çalışır (What Works) anlayışı ve günümüzde gelinen süreçte rehabilitasyon, toplumun korunması ve onarıcı adalet anlayışının karışımı olan bir anlayış söz konusudur (Merrington \& Stanley 2007).

Denetimli serbestlikle ilgili 1970'li yıllarda ve sonrasında önemli bir paradigma farklılığından bahsetmek mümkündür. Tartışmalar rehabilitasyon düşüncesinin etkisizliği ve işlevsizliği üzerinden başlamıştır. Tartışmalara ilk yön veren çalışmalardan birisi Robert Martinson'un 1974 tarihli What Works? Questions and Answers About Prison Reform adl1 çalışmasıdır. Martinson bu yıllarda ortaya çıkan cezaevi reformlarını, rehabilitasyon ve tekrar suç işlemekle ilgili mevcut politikaları eleştirmiştir ve sonuç olarak rehabilitasyonun her yönüyle başarısızlık içinde olduğunu iddia etmiştir (Martinson 1974). Çalışma bu alanda büyük bir etki yapmış ve sonradan Martinson'un raporu şeklinde yer bulmuş ve kitap şeklinde de yayınlanmıştır. Rehabilitasyon düşüncesi üzerine 1970'lerde bu şekilde olumsuz bakış açısı temelinde tartışmaların gelişmesi ceza anlayışı üzerinde etkili olmuş ve sonrasında bu alanda farklı anlayışların ortaya çıkmasını sağlamıştır. Ceza adaleti üzerinde yapılan tartışmalar, neticede sistemin önemli bir parçası haline gelen denetimli serbestliği de derinden etkilemiştir. Bu kapsamda bahsedilmesi gereken ikinci bir çalışma ise 1979 yılında Bottoms ve McWilliams'ın rehabilitasyonla ilgili yeni önerilerde bulundukları çalışmadır (Bottoms \& McWilliams 1979). $\mathrm{Bu}$ çalışmada denetimli serbestlikle ilgili dört amaçtan bahsedilmektedir; suçlular için uygun yardımın sağlanması, suçluların yasal denetimi, suçluları hapis cezasından uzak tutmak ve suçların azaltılması. Daha önceki tartışmalarda sadece rehabilitasyon söz konusuyken bu çalı̧̧mayla yeni tartışmalar açılmıştır. Başka bir çalışmalarında ise etkisiz tedavi paradigması üzerinde çeşitli revizyonlar yapılmasını önermişlerdir (Raynor \& Vanstone 1994). 2006 yılında yine bu alanda yeni bir paradigma McNeill tarafından ortaya atılmıştır. Bu çalışmaya göre önceki anlayışlar rehabilitasyonun nasıl gerçekleşebileceği üzerinde dururken daha sorunlu hale gelmişlerdir. Bu çalışma suçtan vazgeçme paradigması (desistance paradigm) şeklinde rehabilitasyonun esasında suçluların suç işlemekten vazgeçmeleri ile ilgili bir süreci kapsadığını ileri sürmektedir. Buna göre rehabilitasyonun, somut değişimler yoluyla tedavi ve iyileştirme yerine, bu değişimlerin suçlu açısından ne anlama geldiği üzerinde durması gerekir (McNeill 2006). Burada örnek olması açısından bahsedilen akademik tartışmalar görüldüğü gibi rehabilitasyon üzerinde yoğunlaşmış ve ceza adaleti alanında suçluların rehabilitasyonu ile ilgili düşünceleri etkileyerek bu alandaki politikalara yön vermiştir. Sonuç olarak akademik tartışmaların önemli bir oranda ceza adaletine ve ceza adaletinin ise denetimli serbestliğe yön verdiği görülmektedir. 
Denetimli serbestliğin gelişiminin genel anlamda ceza anlayışı ve ceza adaleti alanındaki değişimden etkilendiği ve paralel olarak şekillendiği gerçeği bu şekilde ortaya konabilir. Bu açıklamaların yanında denetimli serbestliğin gelişiminin toplumsal yönünün ortaya konulabilmesi için farklı toplumlarda nasıl ortaya çıktığının ve geliştiğinin de sorgulanması gerekmektedir. Bu şekilde denetimli serbestliğin ortaya çıkışında ve günümüze gelinceye kadar etkili olan toplumsal etkenlerin tespiti sağlanmıştır. Tüm dünyada en köklü denetimli serbestlik sistemine sahip olan İngiltere'de sistemin ilk kaynakları ortaçağda kiliselerin uygulamalarına kadar geri götürülebilir. Cezalandırma anlayışının çok katı olması kiliselerin kanunların katı uygulamalarından kaçan kişilere İncil'de yer alan sığınma hakkını tanımasına sebep oluyordu. 19. Yüzyılda bu uygulama verilen hükmün ya da cezanın belirli bir süre ertelenmesi haline dönüşmüştür. Erteleme sonunda suçlu krala affedilmesi için başvurabilmekteydi. Din adamları kilise mahkemelerinde yargılanabiliyordu. Bu imtiyaz tüm kilise personelini ağır cezalardan kurtarabilmek için ve sonrasında okuma bilen herkes için genişletilmiştir. Okuyabilmek burada kişinin kilise ile bağlantısını ifade etmekteydi. 1827 yılına kadar bu uygulama devam etmiş ve uygulamalardaki eşitsizliklerden dolayı ortadan kaldırılmıştır. İngiltere'de ilk uygulamalardan birisi 1841 yılında yargıç Mathew Hill tarafından gerçekleştirilmiştir. Bu uygulama genç suçlularla ilgili gerçekleştirilmiştir (Canton \& Hancock 2007). 1876 yılında İngiltere'de suçluları alkolden uzak tutmak amaçlı mahkeme görevlileri atanmıştır. 1879 yılında ise sistemin uygulanmasıyla ilgili esaslar düzenlenmiştir. Bu alanda ilk net kurumsal gelişme 1887 yllında Probation of First Offender's Act ile birlikte resmi olarak belirlenmiş ve ilk defa suç işleyen ve cezası 2 yılı geçmeyen kişiler hakkında hükmün ertelenmesi kararı verilmeye başlanmıştır. 1907 yılında yeni bir kanunla sistem ile ilgili usuller düzenlenmiş, daha düzenli hale getirilmiş ve uygulamaların alanı genişletilmiştir. 1925 yılında teşkilat yapısı yeniden düzenlenmiş ve her mahkemede bir görevlinin olmasına, komisyonların oluşturulmasına ve memurların kalitesinin yükseltilmesine karar verilmiştir. 1936'da yeni bir düzenlemeyle sistem ikiye ayrılmıştır. İlk kısım memurların yetiştirilmesine, ikinci kısım ise sistemin genel gelişiminden sorumlu hale getirilmiştir. 1948 yılında yeni düzenlemelerle birlikte mahkemenin suçun niteliği ve suçun karakterini dikkate alması ilkesi getirilmiş ve sistem içerisindeki memurların görev tanımları yeniden yapılmıştır. 1967 y1lında şartlı tahliye ile ilgili görevler, 1973 yılında kamu hizmet ile ilgili görevler sisteme dâhil edilmiştir. 1991 yılında ceza adaleti alanında köklü değişiklikler yapılarak daha ağır suçluların hapis cezası ile cezalandırılması esası benimsenmiştir (Worrall \& Hoy 2005, 40). 2001 yılında sistem National Probation Service adıyla 42 bölgeye ayrılmış ve merkezi Londra olmak üzere yeni bir teşkilatlanma oluşmuştur. Sistem öncesinde İçişleri Bakanlığına bağlıyken 2007 yılında Adalet Bakanlığına bağlı Ulusal Suçlu Yönetim Sistemine (National Offender Management Service) dâhil olmuştur (Nursal \& Ataç 2006; Nellis 2007). İngiltere'de sistemin ilk ortaya çıkışına bakıldığında özellikle gönüllü girişimler ve sivil toplumun etkisi görülmektedir. Sonrasında ise kurumsal gelişmenin mevcut ihtiyaçlar ve toplumsal yapıya uygun bir şekilde geliştiği görülmektedir.

Amerika'da denetimli serbestlikle ilgili ilk uygulama yılı yargıç Peter Oxenbridge Thatcher'in sanığın çağrıldığı anda mahkemede hazır bulunma taahhüdü vermesi üzerine serbest bırakması şeklinde uygulamayla 1830 yılı olmuştur. 1841 yılında bir ayakkabıcı olan John Augustus mahkemeye para ödeyemeyen ve bu nedenle hapse girmek üzere olan bir kişi ile ilgili denetim altında olmak koşuluyla mahkemeyi ikna etmiş ve hükmü erteletmiştir. Augustus bu süre içerisinde suçlunun iş bulmasını ve 1slah olmasını sağlamıştır. Yaklaşık 15 yıllık bir süre içerisinde Augustus 2000 kişiye daha yardım ederek 1slah olmalarını sağlamıştır. Amerika'da denetimli serbestlik alanında Augustus'un sembolik bir değeri bulunmakta ve kendisine denetimli serbestliğin babası denmektedir (Vanstone 2008). 1878 yılında sistem resmi nitelik 
kazanmış ve kurumsallaşmıştır. 1925 yılında federal mahkemelerde uygulanabilmesi için yasa yürürlüğe girmiş, 1957'de tüm eyaletlerde kabul edilmiştir. 1920 yıllarından itibaren psikoloji alanındaki gelişmeler Amerika'da sistem içerisindeki memurların moral veren ve destekleyici danışmanlar olmasını sağlamıştır. 1960 yılından sonra ise topluma yeniden kazandırma ve suçların firsat eşitsizliğinden kaynaklandığı ile ilgili düşüncelerin etkisiyle sistem içerisinde çalışan memurların rolü, suçluların ihtiyaçlarını karşılayan ve bunun için kamu ve özel kuruluşlarla işbirliği yapmak olarak şekillenmiştir. 1970 yılından itibaren suçluların yeniden suç işleme ihtimalini azaltan etkenlerin güçlendirilmesi dâhilinde risk kontrolü olarak yeniden şekillenmiştir (Nursal \& Ataç 2006, 41). 1970'li yıllarda cezalandırma ile ilgili anlayış ve uygulamalar radikal bir şekilde değişmiştir. Denetimli serbestlik de bu değişikliklerden derin bir şekilde etkilenmiştir.

Günümüzde Amerika suç oranlarının en yüksek olduğu ülkeler arasındadır ve halen denetimli serbestlik uygulamalarının yeterli olmadığı ileri sürülmektedir (Morris \& Tonry 1990). İngiltere ve Amerika denetimli serbestliğin ilk ortaya çıktı̆̆ 1 ve geliştiği devletlerdir. Avrupa'da da birçok ülkede sistemin ortaya çıkışı ve gelişmesi ile ilgili benzer yönler bulunmaktadır. Detaylı olarak bakıldığında tüm örneklerde ortak olan bazı yönler görmek mümkündür. İlk olarak sistemin başlangıç aşamasında sivil toplumun önemli bir role sahip olduğu görülmektedir. Sistemin gelişmesi aşamasında ise toplumsal gelişmenin ve buna paralel olarak şekillenen ceza adaleti anlayışındaki değişikliklerin de doğrudan denetimli serbestliği etkilediği ve şekillendirdiği görülmektedir.

Denetimli serbestliğin gelişimini ceza anlayışında ve ceza adaleti alanında ortaya çıkan uluslararası bir uygarlaşma sürecinden ibaret görmemek gerekmektedir. Bu süreç daha karmaşık birçok faktör etkisinde şekillenmiştir. Denetimli serbestlik farklı toplumlarda farklı uygulama ve pratiklerle belirse de tarihsel olarak farklı coğrafyalarda aynı dönemde ortaya çıkmıştır. Aynı dönemde farklı toplumlarda benzer bir şekilde ortaya çıkması, toplumsal gelişmeye paralel olarak aşırı cezalandırma ve ağır cezaevi koşulları üzerindeki insani kaygıların artması ile ilişkili görülebilir. Bunun yanında sosyo-politik bazı çıkarların da denetimli serbestliğin gelişiminde etkili olduğu ifade edilebilir. Bu anlamda modern toplumda devletin toplumsal refah ve toplumun korunması hedefiyle ilgili farklılaşmalar da denetimli serbestliği ortaya çıkartan koşullar olarak kabul edilebilir.

Türkiye için ilk tarihsel kaynaklar Osmanlı dönemine kadar geri götürülebilir. 1851 tarihli ceza kanununda denetimli serbestlik uygulamasına benzer nefy cezası bulunmaktadır. $\mathrm{Bu}$ ceza şekli suçlunun sürgün edilerek başka bir yerde yaşaması ve yaptığı eylemden dolayı pişman olmasını başka bir deyişle sslah olmasını amaçlamaktaydı. Bu cezaya mahkûm edilenler aynı zamanda kürek cezası ya da kal'abendlik gibi yaptırımlara da tabi tutulabiliyordu (Cin \& Akgündüz 2011). Kal'abendlik cezasında suçlu etrafı surlarla kaplı sınırlı bir bölgede hapis olarak tutulmaktaydı ve gerektiğinde kendisiyle ilgili güvenlik önlemleri alınabiliyordu. 1858 tarihli ceza kanununda ise devletin içte veya dişta güvenliğini sarsacak nitelikte olan suçlarda zaptiye nezareti altında bulundurmak cezası uygulanmaktaydı. Bu cezayla suçlunun belirli yerlerde kalması engelleniyor, seyahat etmesi durumunda ise belirli güzergâhları takip etmesi gerekiyordu. Osmanlı'da uygulanan bir diğer uygulama ise şahsa kefalet kurumudur. Bu durumda kefil suçlunun istenildiğinde hazır bulunmasını sağlayan kimsedir ve şahsa kefalet yoluyla tahliye söz konusudur (Akman 2004, 59).

Cumhuriyet döneminde 1926 y1lında kabul edilen ceza kanunu ile birlikte Osmanlı'dan gelen sürgün cezası 1965 yılına kadar devam ettirilmiştir. Diğer bir ceza türü umumiye idaresinin nezareti altında bulundurma cezasıdır. Bu ceza türü şartla salıvermeye benzer bir 
uygulama olarak müebbet ya da 10 yıldan fazla süre hapis cezasından sonra gözetim altında bulundurmak şeklindedir ve 1987 yılına kadar yürürlükte kalmıştır. Benzer uygulamalardan birisi de dilenciler için boğaz tokluğuna çalışma tedbiridir ve 1953 yılına kadar sürmüştür. 1987 yılından başlamak üzere ceza kanunlarında denetimli serbestlikle ilgili çeşitli düzenlemeler olmuştur. 2003 yılına kadar çeşitli kanun maddelerinde zikredilmekle birlikte denetimli serbestliğin ne olduğu ve kurumsal olarak nasıl uygulanacağı ile ilgili açıklayıcı bir bilgi mevcut değildir. Denetimli serbestlik sürekli ceza kanunları ile ilgili tasarılarda yer almış fakat uygulamaya geçirilmemiştir. 2004 yılında Avrupa Birliği uyum süreciyle şekillenen ceza adaleti alanındaki büyük reform hareketinden sonra ve Avrupa ve Amerika'nın yaklaşık 100 yıl gerisinden yeni ceza kanununda ilk defa denetimli serbestlik esasları belirlenmiş ve uygulamaya geçilmiştir. Denetimli serbestlik 2005 yılına kadar karşılaştırmalı hukukun etkileriyle mevzuatta kısmi bir şekilde yer almasına rağmen kurumsal yapının olmamasından dolayı sistem ile ilgili uygulamalar kâğıt üzerinde kalmıştır. Uluslararası hukukta ve ceza anlayışındaki son yüzyıl içindeki gelişmeler denetimli serbestliği tüm dünya ülkeleri için bir zorunluluk haline getirmiştir. Avrupa Konseyi Bakanlar Komitesi 1965 yılında denetimli serbestliği açık ve net bir şekilde tavsiye etmiştir. Bir taraftan uluslararası hukuk bir taraftan ise AB uyum süreci yaşayan Türkiye, denetimli serbestlik sistemini büyük oranda İngiltere modelini temele alarak kendi ceza adalet sistemine aktarmıştır. Türkiye'nin ceza adalet politikalarını büyük oranda siyasi amaçlar doğrultusunda şekillendirmesi denetimli serbestlikle ilgili bazı kurumsal ve toplumsal gereklilikleri de göz ardı etmesi durumunu ortaya çıkarmıştır. Başta sistem için en temel gereklilikler olan sivil toplum desteği, kamu kurumları arasındaki işbirliği ve yetişmiş eleman şartlarını bir kenara bırakarak $\mathrm{AB}$ uyum sürecinde $\mathrm{AB}$ müktesebatının şartlarından birisi olan bu sistemi kısa bir zaman içerisinde ve büyük bir acelecilikle uygulamaya geçirmiştir.

Türkiye'de denetimli serbestliğin uygulanmaya başlanması siyasi bir amaç doğrultusunda $\mathrm{AB}$ üyelik süreci ile ilgili görünmektedir. $\mathrm{AB}$ aynı zamanda aday ülkenin kendi hukuki yapısını AB'ye uyumlu hale getirmesi için çeşitli projelerle aday ülkeyi desteklemektedir. Bu projeler kapsamında Twinning mekanizmasının bir parçası olarak denetimli serbestlik sisteminin Türkiye'ye aktarılması için Türkiye'de Denetimli Serbestlik Hizmetlerinin Geliştirilmesi Projesi üretilmiş ve başlangıç için ilk kurumsal yapı bu proje altında gerçekleştirilmiştir. Kurumsal yapının oluşturulması ve faaliyetlere başlanması büyük bir acelecilikle gerçekleştiği için ilk uygulamalardan sonra bazı değişikliklerin yapılması bir zorunluluk haline gelmiştir. Sistemin uygulanması ile ilgili temel dayanak oluşturan Denetimli Serbestlik Yönetmeliği birçok değişiklik geçirmiş hatta tümüyle yenilenmek zorunda kalınmıştır. Hatta sadece yönetmelikte değil denetimli serbestliğe kaynaklık eden kanun maddeleri de değiştirilmiştir.

İlk dönemde ortaya çıkan değişikliklerden bazıları bu noktada örnek verilebilir. 5402 sayılı Denetimli Serbestlik Hizmetleri Kanunu (2005) 20 Temmuz 2005 tarihinde yürürlüğe girmiştir. $\mathrm{Bu}$ kanun üzerinde ilk değişiklik, 2006 yılında 5560 sayılı Çeşitli Kanunlarda Değişiklik Yapılmasına İlişkin Kanunla (2006), 5. maddeye bir fikra daha eklenerek "Denetimli serbestlik müdürlüğü tarafindan yapılan çağrılara veya hazırlanan denetim planına uyarıya rağmen uyulmamasl, denetimli serbestlik tedbirine ilişkin yükümlülük ihlali sayılır" ibaresi eklenmiştir. Aynı kanunla 14. maddeye bir fikra daha eklenerek "Kamu yararına çalışma yaptırımının infazında 17/7/1964 tarihli ve 506 sayll Sosyal Sigortalar Kanunu hükümleri uygulanmaz" ibaresi eklenmiştir. 2009 y1lında 5402 sayılı kanunun 2. maddesinde yer alan "Asker kişiler hakkında statüleri devam ettiği sürece bu Kanunda belirtilen denetimli serbestliğe ilişkin hükümler uygulanmaz" hükmü anayasaya aykırı bulunarak kaldırılmıştır (Anayasa Mahkemesi, 11.06.2009, E:2006:42, K:2009/73). 2012 yılında 6291 sayılı kanunla birlikte birçok değişikliği içeren geniş bir paket yürürlüğe konulmuştur. Bu değişikliklerle birlikte merkez teşkilatında ve 
taşra teşkilatında da köklü değişiklikler yapılmıştır. Öncelikle kurumun adında bulunan "yardım” ibaresi kaldırılmıştır. Aynı zamanda önceden teşkilat yapısında şube müdürlüğü olarak geçen birimlere müdürlük niteliği kazandırılmıştır. Kanuna 15/A maddesi eklenerek yeni bir uygulama olan elektronik izleme ile ilgili esaslar belirtilmiştir. 26/A maddesi eklenerek teşkilat yapısındaki müdürlüklere müdür yardımcılarının atanmasının ne şekilde olacağı belirtilmiştir. Bunların yanında geçici 6 madde konularak yeni teşkilatlanmada personelle ilgili ortaya çıkan ihtiyaçların, kurumun ihtiyaç duyduğu yeni ödeneklerin ve teşkilat yapısındaki değişiklikten doğan karmaşanın önüne geçilmek istenmiştir (Ceza ve Güvenlik Tedbirlerinin İnfazı Hakkında Kanun ile Denetimli Serbestlik ve Yardım Merkezleri ile Koruma Kurulları Kanununda Değişiklik Yapılmasına Dair Kanun 2012). 20 Aralık 2005'te ise 5402 sayılı kanunun uygulanması ile ilgili "Denetimli Serbestlik ve Yardım Merkezleri ile Koruma Kurullar Yönetmeliği” (2005) yürürlüğe girmiştir. Aralık 2005 tarihinde yürürlüğe giren yönetmelik, 18 Nisan 2007'de uygulamalardaki aksaklıklar göz önünde bulundurularak değiştirilmiş ve tekrar aynı isimde fakat içeriği değiştirilerek kabul edilmiştir. Sonrasında gerek sistemin geliştirilmesi gerekse diğer kanunlardaki çeşitli kanun maddelerindeki değişiklikler nedeniyle yönetmelik "Denetimli Serbestlik Hizmetleri Yönetmeliği" (2013) adıla 5 Mart 2013 tarihinde tekrar ve tümden değiştirilmiştir. Böylelikle sistemin uygulanmasıyla ilgili esasları belirleyen yönetmelik, 2005 - 2013 yıllarını kapsayan 8 yıl içerisinde 3 defa köklü bir şekilde değişmiştir. 2015 ve 2017 yıllarında ise yine kısmi değişikliklere gidilmiş fakat bu değişiklikler çok sınırlı değişiklikler olmuştur.

Sistemin dayandığı temel kanun ve yönetmeliğin değiştirilmesinin yanında 2005 yılından başlayan süreçte sisteme kaynaklık eden kanun maddelerinde de belirgin değişiklikler yapıldığ görülmektedir. Sistemin dayandığ 1 temel uygulamalardan birisi olan "hükmün açıklanmasının geri birakılması" 2006 yılında Ceza Muhakemesi Kanununun (CMK) hükmün açıklanması maddesine "hükmün açıklanmasının geri bırakılması" ibaresi eklenerek uygulamaya konulmuştur (Çeşitli Kanunlarda Değişiklik Yapılmasına İlişkin Kanun, 2006, M.23). Aynı zamanda hangi hallerde hükmün açıklanmasının geriye bırakılacağı ile ilgili esaslar da belirlenmiştir. 2008 yılında başka bir değişiklikle yine CMK 231. maddede hükmün açıklanması ile ilgili ceza sınırı 1 yıl iken değiştirilerek 2 yıl yapılmış, bu şekilde hükmün açıklanmasının geri bırakılmasının alanı genişletilmiştir. Yine aynı değişiklik içinde olmak üzere hükmün açıklanmasının geri bırakılmasının, inkılap kanunlarında yer alan suçlarla ilgili uygulanamayacağı esası getirilmiştir. (Temel Ceza Kanunlarına Uyum Amacıyla Çeşitli Kanunlarda ve Diğer Bazı Kanunlarda Değişiklik Yapılmasına Dair Kanun, 2008, M.562). 2010 yılında, sanığın kabul etmemesi durumunda hükmün açıklanmasının geri bırakılmasına karar verilemeyeceği ibaresi eklenmiştir (Terörle Mücadele Kanunu ile Bazı Kanunlarda Değişiklik Yapılmasına dair Kanun, 2010, M.7). 2014 yılında ise "denetim süresi içinde kişi hakkında kasıtlı bir suç nedeniyle tekrar hükmün açıklanmasının geri bırakılmasına karar verilemez" hükmü getirilerek, hükmün açıklanmasının geriye bırakılması için gerekli şartlarla ilgili çelişkili durum ortadan kaldırılmıştır.

Üzerinde değişiklik yapılan CMK'nın bir diğer maddesi ise yine sistemin uygulamalarında önemli bir yere sahip, "adli kontrol" ile ilgili 109. maddesidir. Aralık 2004'te kabul edilen CMK'nın üzerinde değişiklik yapılmak üzere Haziran 2005'te 109. maddeye bir fikra eklenerek "Şüphelinin, üçüncü fikranın (a) ve (f) bentlerinde yazllı yükümlülüklere tâbi tutulması bakımından, birinci fikrada belirtilen süre sinırı dikkate alınmaz" (Ceza Muhakemesi Kanununda Değiş̧iklik Yapılmasına Dair Kanun, 2005) ibaresi eklenmiş fakat bu ibare daha sonra Temmuz 2012 tarihinde kaldırılmıştır. Aynı tarihte bu madde üzerinde başka değişiklikler de söz konusudur. Birinci fikrada geçen "100. Maddede belirtilen tutuklama sebeplerinin varlı̆̆ halinde, üst sınırı üç yıl veya daha az hapis cezasını gerektiren bir suç sebebiyle yürütülen 
soruşturmada, şüphelinin tutuklanması yerine adlî kontrol altına alınmasina karar verilebilir" hükmünde bulunan 3 yıl ibaresi kaldırılarak süre kısıtlaması ortadan kaldırılmış, bu şekilde adli kontrolün sınırları da genişlemiş̧ir. Bunun yanında adli kontrol sırasında uygulanabilecek yükümlülükler kısmına da 3 madde daha eklenmiştir. Bu madde ile ilgili önemli bir başka değişiklik ise 2006 yllında "Kanunlarda öngörülen tutukluluk sürelerinin dolması nedeniyle salvverilenler hakkında adlî kontrole ilişkin hükümler uygulanabilir" ibaresiyle yasal tutukluluk süresi dolsa da adli kontrol kararı verilebilmesinin önünün açılmasıdır.

Türkiye'de sistemin dayandığı diğer temel bir uygulama alanını oluşturan kanun maddesi ise Türk Ceza Kanununun (TCK) "Kullanmak için uyuşturucu veya uyarıcı madde satın almak, kabul etmek veya bulundurmak ya da uyuşturucu veya uyarıcı madde kullanmak" başlığını taşıyan uyuşturucu maddeler ile ilgili 191. maddesidir. 2005 yılında değişiklikle birlikte ilk olarak uyuşturucu madde etkisi doğuran bitkileri yetiştiren kişiler, kapsamdan çıkartılmış ve kullanmamakla birlikte, kullanmak için uyuşturucu veya uyarıcı madde satın alan, kabul eden veya bulunduran kişiler kapsama alınmıştır. 2006 yılında yine değişiklik yapılarak, 5. fıkrası değiştirilmiş ve 2 fikra daha eklenmiştir. Yeni düzenlemeyle birlikte, mahkemenin hüküm vermeden önce de tedavi ve denetimli serbestlik verebilmesinin önü açılmıştır. Aynı zamanda cezaya hükmedildikten sonra da tedaviye ve denetimli serbestliğe tabi tutulabileceği belirtilmiştir. Bu durumda hükmedilen cezanın infazı ertelenerek denetimli serbestlik kararı verilmektedir. Önceki kanunda tedavi ve denetimli serbestliğe uyan kişinin cezasının infaz edilmiş olacağ şeklinde bir ibare söz konusuyken, bu değişiklikle birlikte, açılmış olan davanın düşmesi gibi yeni bir durum da ortaya çıkmaktadır. 2014 yılında ise 191. madde büyük oranda yeniden belirlenmiştir. İlk olarak öncesinde "bir yıldan iki yıla kadar cezalandırılır" ifadesi değiştirilerek "iki yıldan beş yıla kadar cezalandırllır" hükmü eklenmiş, bu şekilde bu suçun alt ve üst sınırları değişmiştir. İkinci olarak herhangi bir şart aranmaksızın kamu davasının ertelenmesine karar verileceği hükmü getirilmiştir. Bu şekilde ertelemeyle birlikte, sonrasında kişi hakkında kovuşturmaya yer olmadığına dair karar verilebilmektedir. Kişinin belirlenen erteleme süresi içerisinde tekrar uyuşturucu madde satın alması, kabul etmesi veya bulundurması ya da uyuşturucu madde kullanması, ihlal nedeni sayılmakta, ayrı bir soruşturma ve kovuşturma konusu yapılmamaktadır. Bunun yanında öncesinde tedavi kısmı, hükmün bir parças1 halindeyken bu hüküm, çıkartılarak gerek görüldüğünde tedavi öngörülmüştür. 2015 yılında ise bu suçun okul, yurt, hastane, kışla veya ibadethane gibi tedavi, eğitim, askerî v.b. kurumlara iki yüz metreden yakın mesafe içindeki umumi veya umuma açık yerlerde işlenmesi hâlinde verilecek cezanın yarı oranında artırılması hükmü getirilmiştir.

Sistem üzerinde yapılan değişikliklerle ilgili başka bir husus ise günün şartlarının bu değişiklikler üzerinde etkili olması ve ceza adaletinin sahip olduğu sorunların çözümü için denetimli serbestliğin araç olarak kullanılmasıdır. Bu sorunlar özellikle cezaevlerindeki doluluk oranlarının artması ve suç oranlarının yükselmesi şeklinde kendini göstermektedir. 2012 yılında 6291 sayılı kanunla 5275 sayılı Ceza ve Güvenlik Tedbirlerinin İnfazı Hakkında Kanunun 105. maddesinden sonra gelmek üzere 105/A maddesi eklenmiştir. Bu değişiklikle, koşullu salıverilmesine bir yıl veya daha az süre kalan iyi hâlli hükümlülerin talebi hâlinde, cezalarının koşullu salıverilme tarihine kadar olan kısmının denetimli serbestlik tedbiri uygulanmak suretiyle infazına, ceza infaz kurumu idaresince hükümlü hakkında hazırlanan değerlendirme raporu dikkate alınarak, infaz hâkimi tarafından karar verilebilmektedir. Bu değişiklikle birlikte, bu şekilde koşullu salıverme süresi, 1 yıl öne çekilmiştir. Dolayısıyla cezası bir yıl kalan kişiler cezaevinden salıverilmiştir. 2013 yılında bu kapsamda başka bir değişiklik ise 6411 sayılı kanunla, öncesinde aranan iyi halli olmak şartıyla 6 ay açık ceza evinde kalmak şartı, geçici bir madde eklenerek cezanın belirli bir süre infaz edilmesine ilişkin şart 31 Aralık 2015 tarihine 
kadar uygulanmaz hükmü getirilerek, cezaevinde bulunup cezası 18 ay ya da daha az olanların cezaevinden salıverilmesi sağlanmıştır. Bu şekilde 18 aya kadar ceza gerektiren bir suç işleyen kişilerin de hiç cezaevine girmeden aynı gün cezaevinden çıkması sağlanmıştır. Bu değişiklikler, büyük oranda günün şartlarına bağlı olarak yapılan ve örtülü af niteliğinde görülebilecek değişikliklerdir. Cezaevlerindeki doluluk oranlarının azaltılması yönünde yapılan bu değişikliklerin ceza adaleti alanında rasyonel çözüm yolları yerine günü kurtarmaya çalışan politikalarla şekillendiği gerçeğini ortaya koymaktadır.

Ceza adaletini ilgilendiren konularda doğal olarak günün şartlarının ve toplumsal koşulların etkili olması beklenmektedir fakat Türkiye'de bu alanda asıl sorunlardan birisi değişikliklerin ileriye dönük nitelikte yapılamaması şeklinde ortaya çıkmaktadır. Denetimli serbestlik kapsamında son yıllarda dosya sayısının büyük bir artış gösterdiği ve iş yükünün arttığı gözlenmektedir fakat bu iş yükünün altından kalkacak kurumsal yapı ve personel sayısı mevcut değildir. Sistemin amacı dışında kullanıldığının bir göstergesi ise son 10 yıllık dönemde denetimli serbestlik dosya sayısının 50 bin seviyesinden 550 bin seviyesi gibi rekor bir seviyeye çıkmasıdır (Türkmen 2018, 209). Bu sayılar Avrupa'daki tüm devletlerin denetimli serbestlik dosyalarının toplam sayısına neredeyse eşit düzeydedir. Başka bir açıdan ise sistem üzerinde yapılan sık değişiklikler, her yönüyle toplumsal, siyasi ve iktisadi farklı yönlere sahip toplumlardan model olarak alınan kurumsal yapıların Türkiye şartlarına tam olarak uymadığını göstermektedir. Sık değişiklikler ceza adaleti alanında karmaşaya neden olmakta ve toplum açısından suçların cezasız kaldığı ile ilgili genel bir düşünce oluşturarak, ceza adaletine ve dolayısıyla hukuka olan güveni sarsmaktadır. Yeni bir kurumsal yapının uygulamasının gerçekleştirilmesi, elbette bazı zorluklarla karşılaşacaktır. Model olarak alınan ülkelerde de tarihsel süreç içerisinde birçok değişiklik yapılmıştır fakat erginliğine ulaşmış modelleri örnek alan Türkiye'nin, bu ülkelerdeki değişikliklere benzer değiş̧iklikler değil, kendine özgün toplumsal uyumsuzlukların sebep olduğu değişiklikler yaptığ 1 , gözden kaçırılmamalıdır. Ceza adaletini ilgilendiren sorunlar doğrudan topluma yansımaktadır. Bu sorunların çözümü için başvurulan af, örtülü af ya da denetimli serbestlik gibi kurumlar da toplumda bireylere dönük cezalardan kurtulabileceği düşüncesini vermekte, bu durum ise suç oranlarında artışa sebep olmaktadır. Denetimli serbestliğin tam tersine suç oranlarını azaltmak gibi bir misyonu bulunmasına rağmen sistemin Türkiye şartlarında uygulanması görüldüğü gibi bu misyonunu yerine getirememesine, suç oranlarının artmasına sebep olabilmektedir.

\section{Sonuc}

Denetimli serbestlik tüm dünyada çeşitli ülkelerde olduğu gibi Türkiye'de de farklı dinamiklere sahiptir. Ceza adaleti alanında modern dünyanın en işlevsel kurumsal yapılarından birisi olan denetimli serbestliğin Avrupa ve Amerika'daki gelişim sürecine bakıldığında sistemin ilk olarak sivil toplum destekli olarak doğal bir gelişim süreciyle ortaya çıktığı ve sonrasında özellikle kamu kurumları, sivil toplum örgütleri ve gönüllülerle geniş bir işbirliği ağ 1 içerisinde sürdürüldüğü görülmektedir. Fakat Türkiye'de bu şekilde bir gelişim süreci gözlenmemekte, sistemin ilk ortaya çıkışı, ceza adaleti alanında özgün ve işlevsel bir araç olmaktan çok, AB uyum sürecinin bir parçası olarak belirmektedir. Dolayısıyla bu durum denetimli serbestlik uygulamasını tartışmalı hale getirmektedir. Sistem üzerine birçok tartışma ve eleştiri söz konusudur. Bu tartışmalardan en belirgin olanı ise sistemin cezaevlerindeki doluluk oranlarının azaltılması için araçsal kullanımı ile ilgilidir. Diğer bir tartışma ise sistem aracılığıyla örtülü afların çıkartılması ve bu durumun ise kısa vadede suç oranlarını artırması üzerinedir. Ceza adaleti çerçevesinde denetimli serbestlik özelinde yapılan tüm bu tespitler, netice olarak Türkiye'de mevcut toplumsal değişme ya da modernleşme anlayışılla da ilgili görülebilir. 
Modernleşmek için çeşitli kurumsal yapılara duyulan ihtiyaç, denetimli serbestlik gibi kurumsal yapıların diğer ülkelerin gelişmiş örneklerinin model alınmasına neden olmaktadır. Model alınan kurumsal yapılar ise sahip olunan siyasi, iktisadi ve toplumsal yapılara uymamakta ve bu durum ise beraberinde daha büyük sorunların ortaya çıkmasına neden olmaktadır. Ceza sosyolojisi açısından da bu durumu bu şekilde ifade etmek mümkündür. Toplumsal yapı bir toplumda uygulanan cezalara bakılarak ortaya konabilir. Ceza anlayışının tarihsel olarak geçirdiği değişiklikler ve bu cezaların uygulama şekilleri, toplumun birçok özelliğini görünür kılan niteliktedir. Neticede toplum gibi soyut bir varlığı suç ve ceza gibi üzerinde gözlem yapılabilecek değişkenler üzerinden incelemek mümkün olmaktadır. Ceza sosyolojisinin bu kapsamda sunmuş olduğu teorik yapı üzerinden bakıldığında, denetimli serbestlik sisteminin cezalandırma ile ilgili modern bir durumu yansıttığg görülecektir fakat Türkiye' de bu sistemin uygulanmasıyla ilgili ortaya çıkan sorunlar, pratiğe yansıtılmaya çalışılan ceza anlayışıyla toplumsal yapı arasında büyük bir uçurum olduğunu ortaya koymaktadır. Türkiye'nin bu anlamda modern olduğu iddiasıyla uygulamaya çalıştığı denetimli serbestlik sistemi ceza adaleti alanında istenilen başarıyı ortaya koyamamaktadır.

Ceza adaleti alanında tüm dünyada benimsenmiş olan rehabilitasyon anlayışının gereklilikleri, Türkiye'deki kurumsal yapı tarafindan tam olarak yerine getirilememektedir. Siyasi yapının ve toplumun ceza adaleti ile ilgili vizyonu ise son dönemde, örneğin idam tartışmalarında olduğu gibi, cezalandırma açısından rehabilitasyon yerine caydırıcılık özelliği şeklinde görünmektedir. Bu durum Türkiye'de kurumsal ve toplumsal gelişmenin ceza adaleti ile ilgili benimsenen yapıya hazır olmadığını farklı bir açıdan da göstermektedir. Hukuki sistem her ne kadar modern bir görünümle ceza adaleti alanında rehabilitasyon düşüncesini ön plana çıarsa da ceza adaleti ile ilgili pratikte ortaya çıkan mevcut uygulamaların, rehabilitasyon anlayışını hayata geçiremediği görülmektedir. Bir taraftan sistemin cezalandırıcı özelliklerinden vazgeçilmek istenmemekte diğer taraftan ise sistemin rehabilitasyon, onarıcı adalet ve dönüştürücü adalet ilkelerine uygun olması beklenmektedir.

Ceza adalet sisteminde görülen temel problemler hesaba katıldığında suçun işlenmesi ile ilgili sebeplerin çözümü dâhilinde çalışmaların yapılması, daha uygun bir çözüm yolu olarak görülebilir. Cezaevlerinin ağzına kadar dolu olması ceza adaletinin iyi işlediğinin bir göstergesi değildir. Tüm dünyada ceza adalet sistemlerinin önemli bir bileşeni olan denetimli serbestliğin Türkiye'de suçların azaltılması, toplumun korunması ve suçluların tekrar topluma dönüşlerinin sağlanması amaçları etrafinda düzenlemelere gidilmesi gerekmektedir.

\section{Yazarın Notu}

Bu çalışmanın ilk hali 16.02.2018 tarihinde Erzurum'da gerçekleştirilen “Uluslararası Denetimli Serbestlik Bağlaminda Suç Sosyolojisi ve Rehabilitasyon Uygulamaları Sempozyumu"nda sunulmuştur. Çalışma bildirinin gözden geçirilmiş ve genişletilmiş halini içermektedir. 


\section{KAYNAKÇA}

Akman M. (2004). Osmanlı Devleti'nde Ceza Yargllamasl. İstanbul 2004.

Arıcan M. (2009). Ceza Adaleti Sistemi, Etkinliği ve Işsleyişsi. Ankara 2009.

Bottoms A. \& McWilliams W. (1979). "A Non-Treatment Paradigm for Probation Practice". The British Journal of Social Work 9/2 (1979) 159-202.

Canton R. \& Hancock D. (2007). Dictionary of Probation and Offender Management. Devon 2007.

Chui W. H. \& Nellis M. (2003). Moving Probation Forward Evidence, Arguments and Practice. London 2003.

Cin H. \& Akgündüz A. (2011). Türk Hukuk Tarihi. İstanbul 2011.

Durkheim E. (1966). Ceza Evriminin İki Kanunu. Ankara 1966.

Durkheim E. (2006). Toplumsal İşbölümü. İstanbul 2006.

Garland D. (1990). Punishment and Modern Society A Study in Social Theory. Oxford 1990.

Garland D. (1991). "Sociological Perspectives on Punishment". Crime and Justice 14 (1991) 115-165.

Martinson R. (1974). "What Works? Questions and Answers About Prison Reform". The Public Interest 35 (1974) 22-54.

McNeill F. (2006). “A Desistance Paradigm for Offender Management”. Criminology \& Criminal Justice 6/1 (2006) 39-62.

Merrington S. \& Stanley S. (2007). "Effectiveness Who Counts What?”. Eds. L. Gelsthorpe \& R. Morgan. Handbook of Probation. Devon (2007) 428-458.

Morris N. \& Tonry M. (1990). Between Prison and Probation. New York 1990.

Nellis M. (2007). "Humanising Justice The English Probation Service Up to 1972". Ed. L. Gelsthorpe \& R. Morgan. Handbook of Probation. Devon (2007) 25-58.

Nursal N. \& Ataç S. (2006). Denetimli Serbestlik ve Yardım Sistemi. Ankara 2006.

Raynor P. \& Vanstone M. (1994). "Probation Practice Effectiveness and The Non-Treatment Paradigm". The British Journal of Social Work 24/4 (1994) 387-404.

Roth M. P. (2017). Göze Göz Suç ve Cezanın Küresel Tarihi. İstanbul 2017.

Türkmen M. (2017a). "Cezaya Alternatif Bakışlar ve Yeni Bir Disiplin Olarak Ceza Sosyolojisinin İmkanlılı̆̆ı”. Uluslararası Sosyal Araşttrmalar Dergisi 10/52 (2017) 703-720.

Türkmen M. (2017b). “Türkiye'de Ceza Adaleti Alanında Değişimi İzlemenin Bir Aracı Olarak Ceza Popülizmi". Ed. Ş. Aslan \& C. Cinemre, Current Debates In Sociology and Anthropology. London (2017) 381-402.

Türkmen M. (2018). Modernleşme ve Hukuk Türkiye'de Ceza Adalet Sistemi ve Denetimli Serbestlik. İstanbul 2018.

Vanstone M. (2008). "The International Origins and Initial Development of Probation". British Journal of Criminology 48/6 (2008) 735-755.

Worrall A. \& Hoy C. (2005). Punishment in the Community Managing Offenders Making Choices. Devon 2005.

Yücel M. T. (2011). Yeni Türk Ceza Siyaseti. Ankara 2011. 
